\title{
The Effectiveness of Enterpreneurship Learning in Developing Students' Entrepreneurial Intentions
}

\author{
Kakang Harudin, Nanang Fattah, Eeng Ahman \\ Indonesia University of Education \\ kangharudin@gmail.com
}

\begin{abstract}
The main problem of this study is the effectiveness lowness of entrepreneurship learning that effects the intention lowness of student entrepreneurship. The purpose of the study is to describe and to test the variables empirically that influence the students learning effectiveness and entrepreneurship intention. The study applied the survey method. The samples were 357 students from class XI SMK using sampling random proportionate. The data analysis was structural equation modeling that consist of confirmatory analysis and path analysis. Based on the data analysis, the study result are: 1) the high and low of entrepreneurship knowledge is influence positively by students psychology factor, teacher competence, and learning process; 2) the high and low of the industry apprentice result is influenced positively by students psychology factor, teacher competence, learning process, and entrepreneurship knowledge; 3) the entrepreneurship knowledge and the industry apprentice has a positive influence towards the attitude of entrepreneurship, norms perception, and self-efficacy; 4) it is seen from the total that the entrepreneurship knowledge and industry apprentice are the embodiment of entrepreneurship learning effectiveness that has low influence towards entrepreneurship intention, and the strongest relative influence towards the entrepreneurship intention are self-efficacy, entrepreneurship knowledge, industry apprentice, attitude and norms perception.
\end{abstract}

Key word: psychology factor, competence, learning, knowledge, apprentice, attitude, perception, self-efficacy, enterpreneurial intention.

\section{INTRODUCTION}

During the last decades, entrepreneurship has become an important economic and social topic as well as a well-known research topic in the world [1]. Entrepreneurship is important because it leads to increased economic efficiencies, brings innovation to market, creates new jobs, and raises employment levels [2]. Most empirical studies conducted indicate that entrepreneurship can be taught and that education can foster entrepreneurship, which has led to a dramatic rise in the number and status of entrepreneurship programs at vocational schools [3]. The benefits of entrepreneurial education have been praised by both researchers and educators; nevertheless, the impact these programs have on entrepreneurial competencies and the intention to become an entrepreneur has remained largely unexplored [4].

SMK has grown quite rapidly, but on the other hand the majority of graduates are more interested in finding a job or continuing education, rather than pioneering efforts or continue the business of their parents. These symptoms will impact the higher educated unemployment and the emergence of various social and political issues in society. In the approach to education, the symptoms are due to the weakness of entrepreneurship education in schools in shaping the culture, mentality and personality generation of entrepreneurs. Such as achievement motivation, courage to take risks, tenacity, fighting spirit, confidence in his own ability, creativity, innovation and so forth. Weak entrepreneurship education comes down to the effectiveness of learning, in terms of curriculum, educators, learning processes, facilities and learning resources as well as its evaluation.

The focus and the problem of this research is "How will the effectiveness of entrepreneurial learning held at SMK in shaping students' entrepreneurial intentions?". According to the theory of behavior, it is recognized that a person's behavior is largely determined by the person's intentions on behavior. While the intention to behavior depends on people's attitudes toward the behavior [5]. And one of the things will be greatly influenced by the knowledge of it [6]. Of the two theories, shows that entrepreneurial learning to be important in shaping the entrepreneurial intentions. Because knowledge and attitudes formed from the perceived learning process [7].

Previous research is limited to testing the Theory of Planned Behavior, Theory of Entrepreneurial Event and Theory of Entrepreneurial Event without seeing the relationship linkages. This study reveals the relationship these theories in Entrepreunerial Intention Model [7] which states that entrepreneurial intentions directly affected by the entrepreneurial knowledge, attitudes towards entrepreneurship, perceived social norms and self-efficacy. In vocational education entrepreneurial knowledge should be tested in practice industry [8], so as to complete the model of entrepreneurial intention of Linan. In this context, knowledge, industry working practices, attitudes, social norms and selfefficacy is the output from the perceived entrepreneurial learning process. The effectiveness of learning is influenced by psychological factors of students, teacher competence and learning atmosphere [9]. Thus indicated there are 9 (nine) variables that should be observed in this study, namely: actor psychological student, teacher competence, learning environment, entrepreneurial knowledge, the practice of industrial work, attitudes toward entrepreneurship, social norms perceived self-efficacy and intention entrepreneurship, The model of this study complements previous research on entrepreneurial intentions of students who do Iskandar [10].

The $1^{\text {st }}$ Global Conference on Business, Management and

Entrepreneurship 


\section{ENTREPRENEURIAL INTENTIONS}

In social psychology literature, intentions have proved to be a strong predictor of planned individual behaviors, especially when that the behavior is rare, difficult to observe, or involves unpredictable time lags; entrepreneurship is a typical example of such planned and intentional behavior [11]. There is a vast body of literature arguing that intentions play a very pertinent role in the decision to start a new business [12]. As a consequence, during the last recent years, employment status choice models that focus on entrepreneurial intention have been the subject of considerable interest in entrepreneurship research [13]

In these models career intention is seen as the immediate antecedent of behavior (such as starting a business). Intentions in turn are determined by attitudes, and attitudes are affected by 'exogenous influences' such as traits, education, demographics and situational variables [14]. Among intention models, one of the most widely researched is Theory of Planned Behavior (TPB) [15]. The efficacy and ability of TPB to predict entrepreneurial intentions has been proven by number of studies in entrepreneurship [16].

In order to assess the effect of entrepreneurship education program (EEP) or Theory of Entrepreneurial Event [17], the present study follows Fayolle et al, (2006) and Souitaris et al. (2007) to incorporate EEP as an exogenous influence into the TPB. The central factor of the theory is the individual intention to perform a given behavior. Consequently, the model stresses that three key attitudes or independent antecedents predict intention: attitudes toward the behavior (the degree to which the individual holds a positive or negative personal valuation about being an entrepreneur [18], subjective norms (the perceived social pressure from family, friends or significant others [17] to start a new business or not), and perceived behavioral control (the perceived easiness or difficulty of becoming an entrepreneur).

The theory predicts that the greater the favorable attitude and subjective norm with respect to the behavior, combined with a strong perceived behavioral control, the greater the intention will be to perform the particular behavior. This theory has been applied for the prediction of a wide range of human behaviors [19] including entrepreneurial intentions.

\section{RESEARCH METHODOLOGY}

The research design in this research is correlation descriptive and survey method with explanatory. Descriptive design exposes phenomenon that is discussed systematically to get the truth from the investigated problems. The correlation explains the reality and facts from the investigated problems by searching factual data from investigated variables, so the relation between variables can be analyzed by quantitative analysis with relevant statistic test [20].

The research method of explanatory survey is a kind of research that in collecting the data is applied by using questionnaire that is a list of question to collect the answer from respondent (sample). This method has connected with measuring the relationship between two or more variables. This kind of research uses statistical analysis to measure the correlation and influence between research variables [21].

The framework and research design is drawn as follow:
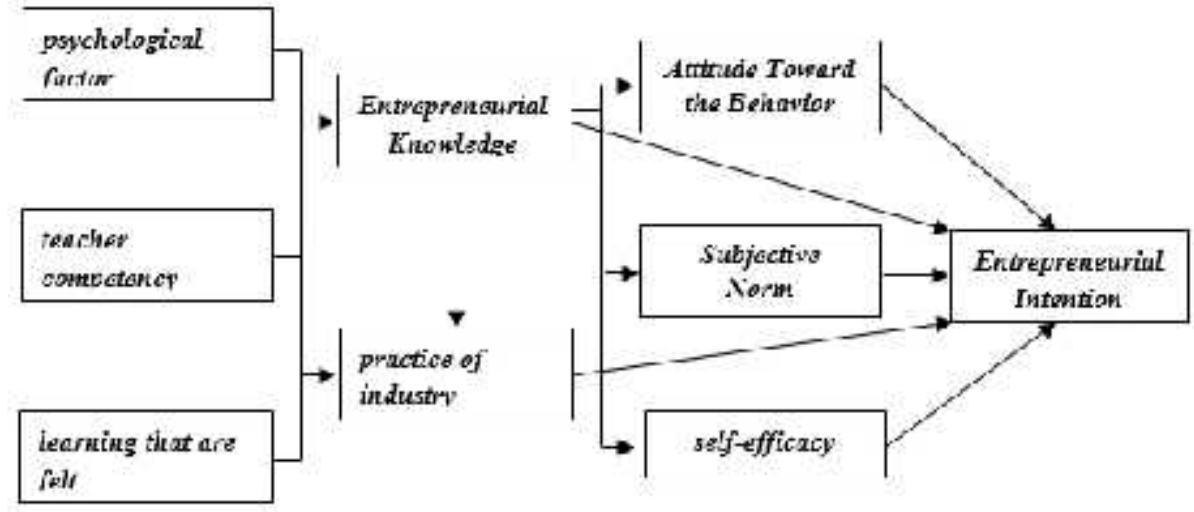

Fig. 1. The framework and research design

This research was applied in SMK schools in Tasikmalaya. The population was 12 schools ( $30 \%$ of 39 schools) with the northern part of the city cluster, the center of town, the eastern city, city of the southern and western parts of the city. The total sample of 357 students (of 3,305 people) class XII were taken using the formula of Slovin (1994) on the business \& manajmen expertise, technology \& communications, of tourism, technology \& engineering, health, fine art \& craft. Data were taken from a questionnaire that was distributed to the selected student contains 80 statements with Likert scale to measure the knowledge and entrepreneurial intentions, 20 questions with a nominal scale to measure entrepreneurial knowledge. Preliminary data tested to 50 students to see the validity and reliability, then the results were analyzed with SEM-path analysis [22]. 


\section{FINDINGS \& DISCUSSIONS}

Based on the result of data analysis, the research found, are as follows: 1) the student's psychology factor that is seen from the perception aspect, interest, and learning motivation [23], the teacher competency that is seen from the pedagogic competency, personality, social, and professional [24], learning process that is felt and seen from connected indicators of learning material with today's condition, contextual learning principles and the support of learning environment [25], the knowledge of entrepreneurship that is seen from the aspect of attitude and entrepreneur behavior, leadership and achievement behavior, making decision and planning a work of entrepreneurship [11], the perception towards the norm [7], self-efficacy [12] and the entrepreneur intention [7] unidimensionally, precise and consistent can be explained by the indicators that is concepted; 2) variable description shows the student psychological factor is categorized positive, teacher competency is categorized high, learning process is categorized moderate, entrepreneurship knowledge is categorized high, norm perception is categorized neutral, self-efficacy is categorized moderate and entrepreneurship intention is categorized moderate.

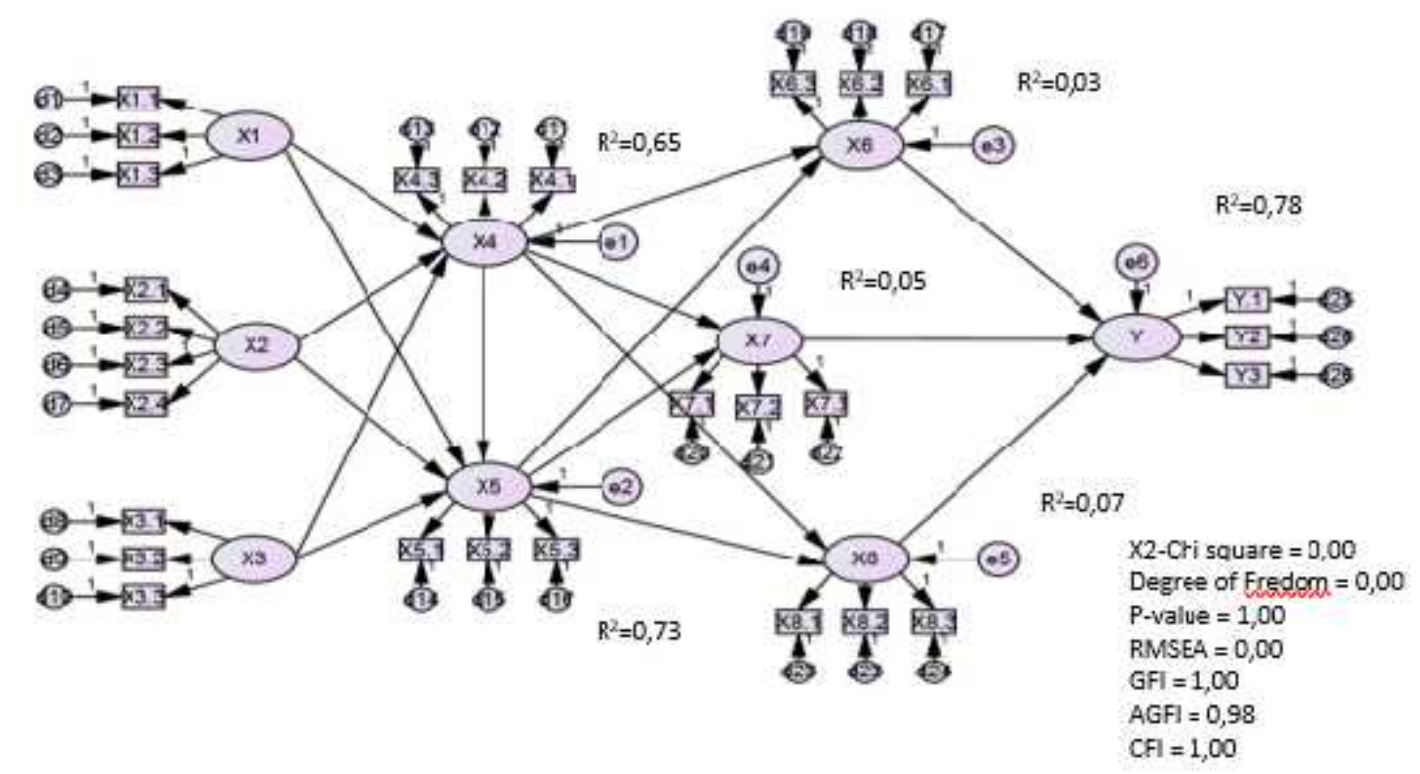

Fig. 2. Source Lisrel Data Result

The result of hypothesis test shows that all research hypothesis are stated accepted with uji goodness of fit statistics.

Student's psychological factor, teacher competency, and learning that are felt influence significantly towards the entrepreneurship knowledge as $65 \%$. This is appropriate with Makmun (2001), Sagala (2008), and Komalasari (2010) opinion that the success of learning is fixed by the raw input, instrument input, and environment input. The learning process of entrepreneurship in SMK of Tasikmalaya is ongoing conventional or it is categorized as entrepreneurial awareness education (Linan 2004). The entrepreneurship education has the goal to increase the amount of people who has good knowledge about entrepreneurship, so they can make such consideration this alternative as a rational choice and can be applied. This education has a direction to one or more element that determines interest such as entrepreneurship knowledge, a will, or the possibility to apply this. Beyond, this entrepreneurship learning model should have the direction towards education for start-up [7] that is the learning that stresses into the practice of the beginning entrepreneurship. This research result has a straight line with the research result of Disman [26] that stated the changes of individual psychology has influence towards the adult age [27], the environment of student psychology has influence towards the learning result at class [28]. The competency is created from the character, knowledge and skill, and experience [18], teacher competency will share effective learning process and results the students' knowledge [19]. The entrepreneurship contextual learning based; that learning is not just memorizing, the students learn from the experience, the knowledge that goes into deep understanding [27].

The factor of student psychology, teacher competency, the felt learning and entrepreneurship knowledge has significant influence towards the practice of industry working as $53 \%$. This has the same opinion with Winkel (1982), learning is all mental activities or psyches that goes in active interaction in an environment that produces changes in understanding management. Learning can be done at class or at industry (apprenticeship). The apprenticeship or double system of education is a kind of education and training application of vocational skills that combine systematically and synchronized the education program at school and a program of mastering skill that achieved directly from working, in good direction to get a certain professional skill level [28]. The partnership concept of school and industry based on Griffiths \& Guile (2003) takes into account for interrelated practices of learning through work experience: acquiring theoretical knowledge, 
dialogic inquiry, boundary crossing and resituating knowledge and skill". The psychological factors are the mental condition of someone that can influence the learning process [29]. The competency is the ability of a teacher to responsibly perform his or her duties appropriately [30]. Teacher competency is together with the factor of student psychology will form the effective learning and one of the indicators is creating or producing knowledge. This knowledge will be applied in the practice of working industry. The relevant of knowledge and student skill with the need of working, also industries will make the success of Link and Match policy [31].

The entrepreneurship knowledge and industry working practice has positive influence towards the student attitude into the entrepreneurship as 24\%. This makes strength the Fishbein \& Ajzen (1975) opinion that the attitude is one of the components in intention towards certain behavior that has two main aspects, that is behavior of trust and evaluation. The behavior of trust is an individual belief of showing or not showing a certain behavior will cause the effects or certain results, and also individual knowledge aspect about attitude object and also individual opinion about something that not goes with the real one. The more positive of the individual belief for the cause of an attitude object, the more positive the individual attitude towards that attitude object, and also vice versa [11]. Evaluation is someone assessment towards the existed results from one attitude. Evaluation will have the effect towards the attitude of assessment from one individual towards each cause or the result that achieved by individual [12]. Thus, the knowledge will create the attitude of trust and the apprenticeship evaluates that trust, so it is to be the whole student attitude of entrepreneurship.

The knowledge of entrepreneurship and the industry practice has positive influence towards felt social norm as $31 \%$. This strengthen Fishbein and Ajzen (1975) opinion that subjective norm is perception of someone towards others thinking that belief has a role and has a hope to do something and how far to have a will in fullfilling that hope. Social figure in subjective norm is significant others for certain people. The important figures can be parents, close friend, husband or wife, or colleague [32]. In learning process the student gain knowledge from the figure of teacher because of his/her model and inspiration, but in apprenticeship the student gain the skill from the teacher as a guide figure and also from colleague/partner. The subjective norm is formed by two aspects that is normative belief and motivation to fulfill the environment demand [11]. The normative belief is someone sight that feels important by an individual that suggest someone to show or not to show certain behavior. On the other hand, motivation to fulfill the environment demands is the readiness of an individual to do or not to do others thinking or opinion that feels important that an individual should or not should show certain behavior. Thus, the knowledge of entrepreneurship and the result of working in the industry can create norm of social that felt by the students.

The knowledge of entrepreneurship and the industry working practice has a positive influence towards the selfefficacy as 36\%. This has the same line with Bandura (1977) that self-efficacy as someone trust for his ability to finish one job. The knowledge as the result of learning and skill as the result of industry working practice will have the influence towards the student self-efficacy. The self-efficacy influences someone trusts at getting the success or not getting the success the certain goal [33]. Self-efficacy, as someone belief with the capability to apply a specific work [34]. Self-efficacy as someone evaluation about his ability $\mathrm{r}$ competency to apply a job, to get a goal, and to handle a problem [35]. The knowledge and skill of student entrepreneurship will direct the student into the high trust to do the entrepreneurship. That all is the result of effective learning process. Efficacy has an important influence towards individual, self-efficacy influences someone belief into getting the success or not getting the success of his fixed goal [36]. Bandura (1997) beliefs that efficacy determines someone's behavior, how strong he can survive in handling the problems and how he get success or fail in finishing his job, and also will affect his behavior in the future. Someone belief in his ability to do the entrepreneurship will affect towards someone will to have the entrepreneurship.

The knowledge of entrepreneurship, the industry working practice, the student's attitude towards the entrepreneurship, the felt social norm, and self-efficacy are together have positive and significant influence towards the intention of student entrepreneurship as $73 \%$. This strengthens the opinion and previous research result. The knowledge of entrepreneurship and social support have an influence towards the intention of entrepreneurship [37]. The industry working practice has an influence towards the entrepreneurship intention by selfefficacy as a bridge variable [38]. The attitude towards the entrepreneurship and the perception about the felt norm is small [39]. The directly felt of social norm has an influence the entrepreneurship intention [40]. The self-efficacy influences the entrepreneurship intention [41]. The result of this research supports and strengthens Entrepreneurial Intention-Based Model, Theory of Planned Behavior, Theory of the Entrepreneurial Event, that are the models that can be one of the approaches in detecting entrepreneurship intention.

The relevance of those three concepts with this research result is if someone evaluated and suggested to have positive behavior (attitude), and if they think that other people will suggest him/her for having the behavior (subjective norm), the result is the higher intensity and they will be happy to be motivated to do that behavior. The attitude and belief for the subjective norm has the high correlation with the behavioral intention and also the real behavior is caused by the environment (Theory of Planned Behavior). The process of forming that behavior can have a change that is caused by trigger events, whether it is positive or negative. The positive trigger events will push someone to make his work come true (Theory of the Entrepreneurial Event). This theory explains that perceived desirability (individual and social value system that influences someone assessment), perceived feasibility, that is someone perception that sees himself having the ability to collect resources (human, social, and financing) to build new work and propensity to act. The modification of those two models is Entrepreneurial Intention Model that is designed to detect the entrepreneurship intention with the educational approach. Linan (2004) summarized that the entrepreneurship intention was influenced by the attitude towards the entrepreneurship, the perception about the social norm and self- 
efficacy. Those are formed because of the knowledge they have about the entrepreneurship from the learning process. The knowledge of entrepreneurship is validated by the industry working practice, as the characteristic of SMK that is double system of education. All of them are framed in the effective learning process.

\section{CONCLUSION \& SUGGESTIONS}

Based on the result of the descriptive and verifiable analysis, the student knowledge of entrepreneurship as a form of entrepreneurship learning effectiveness is positively influenced by the student factor of psychology, the teacher competency level, and the learning that is felt by the students. Those variables have strong and significant influence towards the entrepreneurship knowledge of the students. The industry working practice is a form of the effectiveness of entrepreneurship learning that is positively influence by the psychology factor of the student, teacher competency, the felt learning, and the entrepreneurship knowledge.

The entrepreneurship knowledge and the industry working practice have the positive influence towards the attitude of the student into the entrepreneurship. The higher the level of entrepreneurship knowledge that is supported by the better condition of the industry working practice, the more positive of the student behavior towards the entrepreneurship. The entrepreneurship knowledge and the industry working practice have the positive influence towards the felt social norm. The entrepreneurship knowledge and the industry working practice have the positive influence towards the self-efficacy. The higher the level of entrepreneurship knowledge that is supported by the better condition of the industry working practice, the bigger the level of student self-efficacy at the entrepreneurship. And the entrepreneurship knowledge, the industry working practice, student attitude towards the entrepreneurship, the felt social norm, and self-efficacy have the positive influence towards the student entrepreneurship intention.

Some recommendations that are proposed by the writer, are as follows; in increasing the effectiveness of entrepreneurship learning, the application of teachers training need to increase understanding towards entrepreneurship subject and to introduce contextual method in entrepreneurial learning; to complete the entrepreneurship learning such as books, magazines, journals and other, to complete the library with internet access so that teachers and students can update the entrepreneurship knowledge; to invite successful young entrepreneurs to share their knowledge and to inspire students, it is better that they are from the school and then develop the networking from them as a community, and to develop a cooperation with industry in fulfilling's the apprenticeship journal. To increase the entrepreneurship intention, the government policy is needed in shaping the entrepreneurial day or week as promoted event in creating student achievement and as a competition zone for student or school.

Besides, the government is expected to create business centers in schools as place to train students to entrepreneurship, to give an injection of capital, leaving the management of the school kantik to students, young entrepreneurs do the race on a regular basis and make entrepreneurs comunity with mentors from successful alumni. Need further research to examine the intentions of entrepreneurship by involving other variables with more extensive research coverage.

\section{REFERENCES}

[1] Fayolle, A., B. Gailly, et al. (2007).Towards A New Methodology to Assess Entrepreneurship Teaching Programmes", in Handbook of research in entrepreneurship education. A. Fayolle. Cheltenam, Edward Elgar.

[2] Shane, S., \& Venkataraman, S. (2000). The promise of entrepreneurship as a field of research. Academy of Management Review, 25, 217-226.

[3] Gatewood, E.K. et al. (2002). The effects of perceived entrepreneurial ability on task effort, performance, and expectancy. Entrepreneurship Theory and Practice, 27(2), 187-206.

[4] Sánchez, J.C. (2010). University training for entrepreneurial competencies: Its impact on intention of venture creation. International Entrepreneurship and Management Journal, 7(2), 239-254

[5] Krueger, N. F. Jr., Reilly, M. D., and Carsrud, A. L. (2000). Competing models of entrepreneurial intentions. Journal of Business Venturing, 15, 411-432.

[6] Kolvereid, L. (1996a). Organizational employment versus selfemployment: reasons for career choice intentions. Entrepreneurship Theory and Practice, (20)3: 23-31.

[7] Kolvereid, L. (1996b). Predictions of employment status choice intentions. Entrepreneurship Theory and Practice, 21 (1): 47-57.

[8] Alberti F., Sciascia S., and Poli, A, (2004). Entrepreneurship Education: Notes on an Ongoing Debate. 14th Annual IntEnt Conference University of Napoli Federico II Italy.

[9] Alcalde, F.L., Martín, D.M., González, R. (2002). Characteristics of nascent entrepreneurs in Germany. 42nd ERSA Conference. Dortmund (Germany), 27-31 August 2002

[10] Anderson,J.G. \& D.W. Gerbing. (1988). Structural Equation Modelling in Practice: A Review and Recommended Two-Step Approach. Psychological Bulletin. Vol. 103

[11] Bandura, A and Wood, R.E. (1989). Effect of perceived controllability and performance standards on selfregulation of complex decisionmaking. Journal of Personality and Social Psychology, 56(5), $805-814$.

[12] Basu \& Virick, (1999). Entrepreneurship Education: Notes on an Ongoing Debate. 14th Annual IntEnt Conference University of Napoli Federico II Italy.

[13] Berglund, H. and Wennberg, K. (2006), "Creativity among entrepreneurship students: comparing engineering and business education", International Journal of Continuing Engineering Education, Vol. 16 No. 5, pp. 366-79.

[14] Boyd, N. and Vozikis, G. (1994), "The influence of self-efficacy on the development of entrepreneurial intentions and actions", Entrepreneurship Theory and Practice, Vol. 18 No. 4, pp. 63-77.

[15] Choo, S., dan M. Wong, (2006). Entrepreneurial intention: triggers and barriers to new venture creations in Singapore. Singapore Management Review 28 (2): 47-64.

[16] Clake \& Winch. (2007). Entrepreneurial intention: triggers and barriers to new venture creations in Singapore. Singapore Management Review 28 (2): 47-64.

[17] Collins, C. ed. (1993). Competencies: The Competencies Debate In Australia Education And Training. Curtin: Australian College of Education.

[18] Cromie, S., (2000). Assessing entrepreneurial inclinations: some approaches and empirical evidence. European Journal of Work and Organizational Psychology 9 (1) 7-10.

[19] Cromie, S., (2000). Assessing entrepreneurial inclinations: some approaches and empirical evidence. European Journal of Work and Organizational Psychology 9 (1) 7-10.

[20] David R. Krathwohl. (2002). A Revision of Bloom's Taxonomy, An Overview (Ohio: Theory Into Practice, vol 41 number 4). 
[21] Dissayanake,D.M.N.S.W. (2013). The Impact Perceived Desirability and Perceived Feasibility among Undergraduated Students in Sri Lanka : An Extended Model. The Kelaniya Journal of Management, 2(1),pp.33-57

[22] Elliot, M.A, Armitage, C.H and Baughan, C.J. (2003). Drievrs Compliance eith Speed Limits : An Application of the Theory of Planned Behavior. Journal of Applied Psyhchologi. 88 (5) pp 964-972.

[23] Erride, A. dan Perry, S. (1994). The Validity and Value Of National Vocational Qualification. British Journal of Education and work 7, No.2.

[24] Fletcher, J. (1990). Self esteem and cooperative education: A theoretical framework. Journal of Cooperative Education, 26(3), 41-55.

[25] Frinces (2011). Self esteem and cooperative education: A theoretical framework. Journal of Cooperative Education, 26(3), 41-55.

[26] Gagne dan Briggs. (1979). Future Direction for Vocational Education In Australian Secondary Schools. Australian and New Zealand Journal of Vocational Education Research 5, No. 1 (May):77-108.

[27] Gibson, James L., (1989). Budaya Organisasi dan Manajemen. (Terjemahan) Penerbit Erlangga. Jakarta .

[28] Gonezi, A. (1997). Future Direction for Vocational Education In Australian Secondary Schools. Australian and New Zealand Journal of Vocational Education Research 5, No. 1 (May):77-108.

[29] Hadiyanto dan Subijanto (2002). Pengembalikan Kebebasan Guru untuk Mengkreasi Iklim Kelas dalam Manajemen Berbasis Sekolah (MBS). Bandung: Jurnal Pendidikan

[30] Indiarti, N. dan Rostianti R. (2008). Intensi Kewirausahaan Mahasiswa: Studi Perbandingan Antara Indonesia, Jepang dan Norwegia. Jurnal Ekonomika dan Bisnis Indonesia, Vol.23, No. 4.

[31] Morgan, (1986). Entrepreneurship and female youth:knowledge, attitude, gender differences, and educational practices. Journal of Business Venturing 13 (1): 77-88.

[32] Nursito, (2013). Kemajuan Bangsa, Pendidikan dan Kewirausahaan. Pidato Ilmiah pada penganugrahan gelar Doktor Honoris Causa. Universitas Pendidikan Indonesia. 17 Maret 2011.
[33] Kalla, M.Y. (2011). Kemajuan Bangsa, Pendidikan dan Kewirausahaan. Pidato Ilmiah pada penganugrahan gelar Doktor Honoris Causa. Universitas Pendidikan Indonesia. 17 Maret 2011.

[34] Kourilsky, M. L. and Walstad, W.B. (1998). Entrepreneurship and female youth:knowledge, attitude, gender differences, and educational practices. Journal of Business Venturing 13 (1): 77-88.

[35] Krueger, N. F. Jr., Reilly, M. D., and Carsrud, A. L. (2000). Competing models of entrepreneurial intentions. Journal of Business Venturing, 15, 411-432.

[36] Linan, F. (2004). Intention-based Model of Entrepreneurship Education. Annual IntEnt Conference 2004. Naples Italy.

[37] Segal, G., and Borgia, D., Schoenfeld, J. (2005). The Motivation to Become an Entreprenur. International Journal of Entrepreneurial Behavior \& Research, 11, 42-57

[38] Sibthorp, Jim. (2003). An Empiracal Look at Walsh and Golins' Adventure Education Process Model: Relationships between antecedent Factors, Perceptions of Characteristics of an Adventure Education Experience, and Changes in Self-Efficacy. Journal of Leisure Research, Vol. 35. No. 1, 80

[39] Wang, Weijun; Lu, Wei; Millington,JK (2011). Determinant of Entrepreneurial Intention Among College Students in China and USA. Journal of Global Entrepreneurship Research, 1 (1), pp. 35-44

[40] Wibowo, Muladi. (2011). Pembelajaran Kewirausahaan dan Minat Wirausaha Lulusan SMK. Jurnal Vol. 6 No.2 Fakultas Ekonomi Universitas Islam Batik

[41] Vemmy, (2014). Kajian Model Empiris Perilaku Berwirausaha UKM DIY dan Jawa Tengah. Jurnal Manajemen dan Kewirausahaan, Vol.10, No. 2. 